\title{
The Hancock Library of Biology and Oceanography*
}

Mrs. Halmos is librarian, the Hancock Library of Biology and Oceanography, Los Angeles.

$\mathrm{O}$ CEANOGRAPHICAL RESEARCH began in fairly recent times and has developed a considerable body of literature only during the present century. The earliest studies depended upon logs kept by sailors, as in the book by M. F. Maury, I 855 , entitled The Physical Geography of the Sea, to which title he later added the words and Its Meteorology. In fact, these early records were of value mainly in the field of meteorology, although some attempts were made to explore currents, temperatures, and bottom contour and composition. But it was not until better instruments for recording and exploring the various phenomena had been invented, that oceanographical research could be put upon a systematic basis.

Much of the information we have about the ocean has come from the observations of scientific expeditions, especially those into polar regions, such as the voyages of the two Rosses, Sir John to the north, Sir James to the south. 1872 saw the start of one of the greatest purely scientific expeditions ever undertaken, that of the "Challenger," which added immeasureably to our knowledge of the ocean, by its accurate measurements and careful records. Other countries followed the example of Great Britain in sending out expeditions, such as that of the "Gazelle" of Germany, and the "Tuscarora," the

* Presented at meeting of ACRL Pure and Applied Sciences Section, Los Angeles, June 23, I953.
"Blake," and the "Albatross" of the United States. In I902, at Stockholm, was founded the International Council for the Study of the Sea, which has been very influential in organizing and encouraging oceanographical research. Since that time, the volume of publication has increased tremendously in this field, and its character has changed also.

Dr. Dale F. Leipper, Head of the Department of Oceanography of the Agricultural and Mechanical College of Texas, in a recent article on "Oceanography and the Special Library," has given an interesting discussion of oceanographical literature and the problems involved in trying to build up an adequate library in this field. He divides the study of oceanography into five aspects: the biological, the chemical, the geological, the physical, and the physical and meteorological. For each of these aspects, three groups of library materials are needed. For example, in biology, there are the materials which pertain to all plants and animals, terrestrial and marine; this portion of the library is by far the largest. Then there will be those works dealing with marine biology, that is, the plants and animals of the sea; and last, a comparatively small collection of works on the purely oceanographical aspect of biology, the study of plants and animals in the sea, involving considerations of currents, temperature, weather, chemistry of the water, and chemical reactions, ocean bottom, and so forth. While this last group is small, it presents many problems in acquisition and recording, 
classifiying and cataloging, because so much of it is in the form of mimeographed reports issued in limited numbers, which quickly go out of print and become unobtainable. An oceanographical institution which is not located near a large scientific library must have in its own library not only the last and smallest group, but must also provide for the use of its research staff the basic works in the various fields involved in the study of the sea-biology, geology, geography, meteorology, chemistry, physics, and related fields. An oceanographical library on or near a university campus has, then, a decided advantage in that it can draw on the university library for much, if not all, of the basic material, and probably for some of the marine portion. The available funds and the time of the library staff can then be devoted to securing and caring for the purely oceanographical material.

Another advantage in being part of a university campus comes from the possibility of close cooperation with the various colleges and departments of the university. This is a two-way advantage, as the oceanographical library is available to university scientists who may wish to use the material there or who are working on special problems with the members of the oceanographic staff; and it offers to the oceanographical institution an opportunity to draw into its work qualified scientists from other fields, as well as to develop interest in oceanographical work among the graduate students of the university.

The Allan Hancock Foundation is an example of such an institution so located. We are able to depend upon the university library for much of the material we need, especially in the fields of physics, chemistry, biochemistry, and bacteriology. There is very close cooperation between the staff of the foundation and the faculty of the university, with members of the staff offering courses in the university and faculty mem- bers given space and facilities in the foundation for research; and Hancock research scholarships are available to graduate students in the university.

The Hancock Foundation is still young, having been founded in 1938 by Captain Allan Hancock, our director. 'The following year, plans were begun for a building to house the institution, and this building was formally dedicated in January, I94I. The need for a library was recognized from the start, and by the time the building was dedicated, the foundation had acquired a library of more than a thousand volumes, including the reports of the Challenger and Siboga expeditions, the voyages of Albert I, prince of Monaco, and d'Orbigny's voyage to South America. The library continued to grow, acquiring more reports of scientific expeditions, as well as important basic works such as those of Kiener, Reeve, Martini and Chemnitz, and Bleeker. By 1944, the library possessed over 3000 volumes, including the reports of fifteen of the more important scientific voyages in the Pacific. Thus early was started our special emphasis on the results of scientific expeditions.

In 1944, Captain Hancock purchased for the foundation the foreign serials from the library of the Boston Society of Natural History, and in 1946 he purchased from the same society the greater part of its valuable collection of books and American serials. Thus in the space of about two years, the library grew from a collection of 3000 volumes to one of 75,000 volumes and 100,000 reprints and pamphlets. Since then the Hancock Library has been adding to its holdings, both by purchase and exchange, so that we now have a collection of over 85,000 volumes and approximately 125,000 reprints and pamphlets.

In order to explain just how valuable and extensive a library the foundation has been able to acquire through the generosity of Captain Hancock, I should like to take a 
few minutes to tell you something about the library of the Boston Society of Natural History, which was the second oldest natural history library in this country.

The Boston Society of Natural History was organized as a result of a "meeting of gentlemen favorable to the formation of a Society for the study of Natural History, held at Dr. Channing's Rooms on the evening of the 9th of Feby I830." Among the charter members of the society were such men as Amos Binney, Walter Channing, Simon E. Greene, Gamaliel Bradford, Henry Godman, Benjamin D. Greene, Martin Gay, A. A. Gould, and D. Humphreys Storer. The need for a library was recognized from the beginning, and among the first officers chosen on May I3, I830, was a librarian; and in January, I83 I, a library committee was appointed to receive donations for the library. At the annual meeting of May 4th, I83I, the first donations to the library were announced-thirty books and two pamphlets.

In I 834 , the first number of the society's Journal appeared. An exchange list was at once established with other scientific institutions increasing until there were over five hundred names on the list. Thus the Journal and later publications were important factors in the steady growth of the library. The second chief source of books was the generous gifts of members and friends, who from time to time made valuable donations or bequeathed their private libraries to the society. There are records of many such, as in I845 a gift of fifty volumes from Dr. Francis Boott, of London; the bequest, in I 855 , of the library of James Brown, of the publishing firm of Little, Brown, who left to the society his splendid collection of expensive works in ornithology; the fine library of Amos Binney, at one time president of the society, was donated by his widow; and in 1863 came similarly the large botanical library of
Benjamin D. Greene, comprising over I 500 volumes. When, in I864, Samuel $\mathrm{H}$. Scudder became librarian, he devoted great energy to increasing the number of exchanges and did much to perfect the series of publications thus received. At his death, he left his wonderful private library of entomological literature to the society, thus putting it in the high place in this field which it held. In 1836 , a group of eleven members and friends subscribed to Audubon's Birds of America for the library. When, in I840, Colonel Thomas H. Perkins presented to the society another copy which, in the words of the secretary, "was an early impression and is probably unsurpassed by any in the country," the first set was sold and the money used to buy other important works in ornithology. In 1843 , ten members subscribed to Audubon's Quadrupeds for the library, and in $1932 \mathrm{Dr}$. Henry Jackson gave a nearly complete set of Audubon and Bachman's Quadrupeds of North America, in the original covers. In I 854, the Hon. Francis C. Gray presented to the library a beautifully bound set of the Histoire Naturelle des Mammifères, by Geoffrey Saint-Hilaire and Cuvier. This tradition was maintained and the library was continually enriched by gifts, until in May, 1936, the librarian reported:

I doubt whether many of our members or outsiders realize the tremendous value of our library. We hardly did ourselves until we began getting out our treasures for repairs. .. We are especially strong in old sets of books and serials, and few libraries in the country can even equal us in this respect.... A library like this can rightly hope to enlist the support of antiquarians and bibliophiles as well as that of naturalists.

In the book, The Boston Society of Natural History, 1830-1930, is the following description of the library:

The Library is devoted to Natural History in its wider sense and contains many 
sets or single volumes, notable for their rarity, value, or beauty. Among the last are the beautiful sets of original elephantfolio plates of Audubon's Birds of America and the Quadrupeds. Hardly less elegant are the complete works of Gould, including sumptuously bound monographs on various groups of brilliantly colored birds, such as the humming birds and the toucans, illustrated by magnificent colored plates in folio size. There is also a copy of the rarer volume on the Odontophorinae or quails, and a set of the Birds of Australia. The earlier classic works of Wilson and Catesby, the former on birds, the latter on plants and animals of the Carolinas, are also represented. Several volumes of colored figures by Abbot, illustrate the birds and insects of Georgia, and are exceedingly rare if not almost unique. Other older works include beautifully illustrated volumes on shells, such as the series of Reeve's Conchologia Iconica and Conchyliorum Cabinet of Martini and Chemnitz. More modern works of great beauty and value are the series of volumes of the Biologia Centrali-Americana, the Flora of Brazil, Sargent's Sylvia, and others too numerous to name in a brief paragraph. Then there are many sets of the transactions of learned societies, some of whose publications extend back for a century or more. Special efforts have been made to complete the more valuable of these, so that some at least are more nearly perfect than are to be found elsewhere in the vicinity. Others are less ancient but rare in this neighborhood, such as the fine series of illustrated volumes of the Bombay Society of Natural History. Numerous old works of a bygone day are represented, whose value lies in their quaintness or other historic importance as source books, or records of the beginnings of a more exact knowledge of Natural History. Among these are the great volumes of Gesner's Natural History, written in Latin and Greek, with quotations from the writers of antiquity concerning the animals known in a past century, for it dates from 1555 ; while a second work of the same date and of equal importance is the volume on birds by the French savant, Belonius, almost the first treatise on this group of animals.
There are numerous works on insects that are equally valuable through their rarity and historic association. Examples are the little book by Bilberg on the insects of Scandinavia, and one by the German, Hübner, on butterflies, while another almost unique copy in this part of the world is Koch's series of hand-colored plates and text issued on separate sheets of small size, monographing the mites and allied types, nearly a century ago. Several of the rare works of Peter Pallas, an illustrious pupil of the great Linnaeus, are here also, and include the results of his early investigations in the Natural History of Siberia and northern Asia.

We are adding to our library both by purchase and by exchange. The Hancock Library now has about three hundred and fifty exchanges in more than fifty countries, and new ones are being arranged as we can find time. We are trying to complete broken sets, and to add those titles in our own special field which were lacking in the Boston Society library. As the work of the Allan Hancock Foundation is primarily in marine biology and oceanography, we are concentrating on building up the titles in these fields, and the library of the University of Southern California is assuming much of the responsibility for continuing and completing sets in the other fields covered by the collection. The two libraries together thus offer a wealth of material to the research scholar in any field of the natural sciences.

However, we can still say with a former librarian of the Boston Society of Natural History :

What a convenience it would be if it were possible for an investigator to go to a single library and there find all the journals, books and transactions of learned societies that have ever been published, dealing with even this one branch of science. Such an ideal, however, seems infinitely far from realization! 